\title{
Micro-International Units per Milliliter per Milligram per Day
}

National Cancer Institute

\section{Source}

National Cancer Institute. Micro-International Units per Milliliter per Milligram per Day.

NCI Thesaurus. Code C119514.

A unit of concentration (biologic activity) equal to one micro-international unit per

milliliter, divided by milligrams per day. 